Article

\title{
Synthesis and Characterization of Celecoxib Derivatives as Possible Anti-Inflammatory, Analgesic, Antioxidant, Anticancer and Anti-HCV Agents
}

\section{Ş. Güniz Küçükgüzel ${ }^{1, *}$, İnci Coşkun ${ }^{1}$, Sevil Aydın ${ }^{1}$, Göknur Aktay ${ }^{2}$, Şule Gürsoy ${ }^{2}$,} Özge Çevik ${ }^{3,4}$, Özlem Bingöl Özakpınar ${ }^{3}$, Derya Özsavcı ${ }^{3}$, Azize Şener ${ }^{3}$, Neerja Kaushik-Basu ${ }^{5}$, Amartya Basu ${ }^{5}$ and Tanaji T. Talele ${ }^{6}$

1 Department of Pharmaceutical Chemistry, Faculty of Pharmacy, Marmara University, Haydarpaşa, 34668 İstanbul, Turkey; E-Mails: coskun.inci@yahoo.com (İ.C.); sevil.aydin@marmara.edu.tr (S.A.)

2 Department of Pharmacology, Faculty of Pharmacy, Inonu University, 44280 Malatya, Turkey; E-Mails: gaktay@inonu.edu.tr (G.A.); sulegursoy@hotmail.com (Ş.G.)

3 Department of Biochemistry, Faculty of Pharmacy, Marmara University, Haydarpaşa, 34668 İstanbul, Turkey; E-Mails: dagdevirenozge@gmail.com (Ö.Ç.); ozlem.bingol@marmara.edu.tr (Ö.B.Ö.); derya.ozsavci@marmara.edu.tr(D.Ö.); azize.sener@marmara.edu.tr (A.Ş.)

4 Department of Biochemistry, Faculty of Pharmacy, Cumhuriyet University, 58140 Sivas, Turkey

5 Department of Biochemistry and Molecular Biology, UMDNJ-New Jersey Medical School, 185 South Orange Avenue, Newark, NJ 07103, USA; E-Mails: kaushik@umdnj.edu (N.K.-B.); basu.amartya@gmail.com (A.B.)

6 Department of Pharmaceutical Sciences, College of Pharmacy and Allied Health Professions, St. John's University, Jamaica, NY 11439, USA; E-Mail: talelet@stjohns.edu

$\dagger \quad$ This work was partly presented at the ISTE-C, P.988-993, İstanbul, Turkey, 7-9 December 2012.

* Author to whom correspondence should be addressed; E-Mail: gkucukguzel@marmara.edu.tr; Tel.: +90-216-349-12-16; Fax: +90-216-345-29-52.

Received: 31 January 2013; in revised form: 12 February 2013 / Accepted: 10 March 2013 / Published: 21 March 2013

Abstract: A series of novel $N$-(3-substituted aryl/alkyl-4-oxo-1,3-thiazolidin-2-ylidene)-4[5-(4-methylphenyl)-3-(trifluoromethyl)-1H-pyrazol-1-yl]benzenesulfonamides 2a-e were synthesized by the addition of ethyl $\alpha$-bromoacetate and anhydrous sodium acetate in dry ethanol to $N$-(substituted aryl/alkylcarbamothioyl)-4-[5-(4-methylphenyl)-3-(trifluoromethyl)-1H-pyrazol-1-yl]benzene sulfonamides 1a-e, which were synthesized by the reaction of alkyl/aryl isothiocyanates with celecoxib. The structures of the isolated 
products were determined by spectral methods and their anti-inflammatory, analgesic, antioxidant, anticancer and anti-HCV NS5B RNA-dependent RNA polymerase (RdRp) activities evaluated. The compounds were also tested for gastric toxicity and selected compound 1a was screened for its anticancer activity against 60 human tumor cell lines. These investigations revealed that compound 1a exhibited anti-inflammatory and analgesic activities and further did not cause tissue damage in liver, kidney, colon and brain compared to untreated controls or celecoxib. Compounds 1c and 1d displayed modest inhibition of HCV NS5B RdRp activity. In conclusion, N-(ethylcarbamothioyl)-4-[5-(4methylphenyl)-3-(trifluoromethyl)-1H-pyrazol-1-yl]benzenesulfonamide (1a) may have the potential to be developed into a therapeutic agent.

Keywords: anti-inflammatory; anticancer; celecoxib; hepatitis C NS5B; sulfonylthiourea

\section{Introduction}

Arachidonic acid is an unsaturated fatty acid liberated from phospholipids of cell membranes. Phospholipid hydrolyses cause arachidonic acid release. The eicosanoids are formed by two different routes; namely via the cyclooxygenase (COX) and lipoxygenase (LOX) pathways. Leukotrienes, derived from the lipoxygenase pathway, are responsible for allergy, inflammation and other pathological situations. Cyclic endoperoxides, derived from cyclooxygenase pathway, are converted to derivatives of prostacyclin, prostaglandin $\mathrm{E}$, prostaglandin $\mathrm{F}_{2 \alpha}$, tromboxane $\mathrm{A}_{2}$ under the action of several enzymes. Prostacyclins and prostaglandins (PG) are major mediators of hyperalgesia which means sensitization of central neurons and an increased response to a painful stimulus. Hyperalgesia is induced by non-steroidal anti-inflammatory drugs (NSAIDs) with the inhibition of cyclooxygenases. Thus, the production of prostaglandin and prostacyclin is hindered [1].

There are two main types of cyclooxygenase that are found in the human body. The enzyme known as COX-3, a COX-1 variant, take place in cerebral cortex and is particularly sensitive to parasetamol. COX-1 is expressed in tissues. In contrast to COX-1, COX-2 is important has a role in ovulation, birth processes and inflammation. The other difference between COX-1 and COX-2 is tissue expression. COX-1 is constitutively expressed in almost all tissues. COX-2 expression is highly restricted, for instance the tissues in patients with malignant and premalignant tumors express increased levels of COX-2.

Factors contributing to chronic inflammation appear to be associated with increased risk of epithelial cancer. The positions where inflammation occurs, cytocine based COX-2 induction results in prostaglandin increases. The role of COX-2 enzyme in aspects of carcinogenesis like proliferation and apoptosis is also effective. Inflammation induced by COX-2 in proliferation mainly depends on the production of prostaglandins. This mechanism of COX-2 in carcinogenesis causes cancer. In addition, COX-2 plays a role in the early stages of hepatocarcinogenesis [2-4].

NSAIDs are known as targets of COX in arachidonic acid metabolism and are useful clinical therapeutics for the treatment of inflammation, pain and inflammation-related disorders. Epidemiologic studies have shown that regular use of NSAIDs may reduce the risk of cancer among patients. Furthermore, some NSAIDs have anticancer activities in vitro. However, the mechanisms that 
lead to inhibition of polyp formation are not clear. Researchers have stated that the antitumor activities depend on the inhibition of prostaglandins [5,6]. It is also stated that NSAIDs are responsible for the regulation of normal apoptosis in colorectal polyps and in several cancer cell lines which have lost their polyposis coli gene function [7].

Oxidative stress can be caused by an elevation in the concentration of reactive oxygen species (ROS) [8]. ROS react with any cellular structure and can initiate cell death by necrosis or apoptosis [9-11]. Thus, enhanced oxidative stress can caused tissue damage. A large number of drugs and compounds can stimulate the generation of ROS and increase tissue damage [11].

Besides, the presence of a pyrazole moiety and potent activity make pyrazofurin (Figure 1) a useful precursor to synthesize new compounds having antiviral activity. Researchers have reported that the compounds including pyrazole moieties are effective against the HCV virus [12-15]. The compound SC-560 (Figure 1) as a celecoxib analog, is a selective inhibitor of COX-1 and COX-2. Because of the efficacy against HCV, SC-560 and its derivatives are drug candidates for further studies [16].

Figure 1. Pyrazofurin and SC-560.

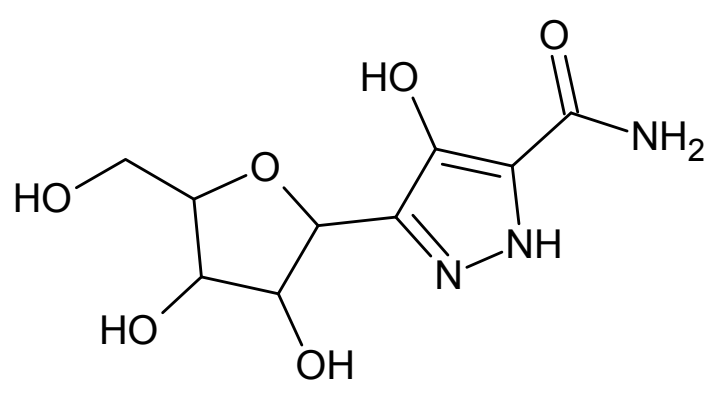

Pyrazofurin

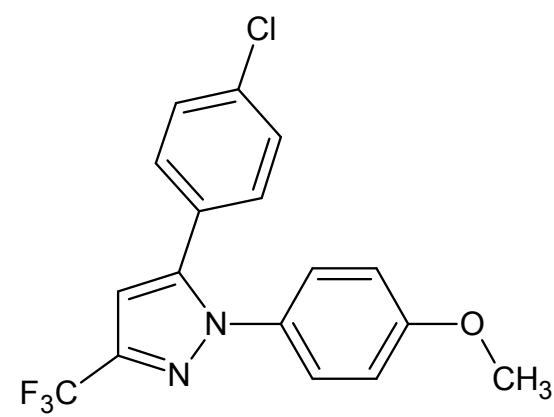

SC-560

Celecoxib, a selective potent COX-2 inhibitor, is currently Food and Drug Administration-approved for chemoprevention in familial adenomatous polyposis based on demonstrable inhibition of colon polyp formation, further solidifying the use of this agent in cancer therapy [17] and proliferation of HCC cell lines [18]. In addition, celecoxib was shown to be a gastrointestinally safe anti-inflammatory analgesic agent.

The sulfonylthioureido group has emerged as the most favourable pharmacophore. Sulfonylthioureido and 4-thiazolidinone groups in combination resulted in anticancer [19] and anti-inflammatory [20] activities. Celecoxib [4-[5-(4-methylphenyl)-3-(trifluoromethyl)-1H-pyrazole-1-yl]benzenesulfonamide], which has a sulfonylamide moiety was used as a starting compound for synthesizing new sulfonylthioureas and after the characterization of their structure these sulfonylthioureas were refluxed with alkyl $\alpha$-halogenoacetates and anhydrous sodium acetate in absolute ethanol to provide sulfonyliminothiazolidine-4-ones.

The structures of the synthesized compounds were elucidated by chemical and spectroscopic methods, and their biological activity was determined. Furthermore, the ulcerogenic and acute toxicity profiles of the synthesized compounds were determined. 


\section{Results and Discussion}

\subsection{Chemistry}

In the present study, we report the synthesis of celecoxib derivatives bearing sulfonylthiourea and 4-thiazolidinone ring systems (Scheme 1). N-(substituted carbamothioyl)-4-[5-(4-methylphenyl)-3(trifluoromethyl)-1H-pyrazol-1-yl]benzenesulfonamides 1a-e were prepared with substituted isothiocyanates and anhydrous $\mathrm{K}_{2} \mathrm{CO}_{3}$ in dry acetone starting from celecoxib. $N$-(3-Substituted-4-oxo1,3-thiazolidine-2-ylidene)-4-[5-(4-methylphenyl)-3-(trifluoromethyl)-1 $H$-pyrazol-1-yl]benzenesulfonamide derivatives $2 \mathbf{a}-\mathbf{e}$ were synthesized by the reaction of ethyl $\alpha$-bromoacetate and anhydrous sodium acetate in dry ethanol with the sulfonylthioureas 1a-e. Purity of the synthesized compounds was determined by elemental analysis. Structures of these compounds were characterized using FT-IR, ${ }^{1} \mathrm{H}-\mathrm{NMR},{ }^{13} \mathrm{C}-\mathrm{NMR}$ (only 2c) and HR-MS (1a and 2a) spectral data.

Scheme 1. Synthesis of celecoxib derivatives $\mathbf{1 a}-\mathbf{1 e}, \mathbf{2 a}-\mathbf{2 e}$.

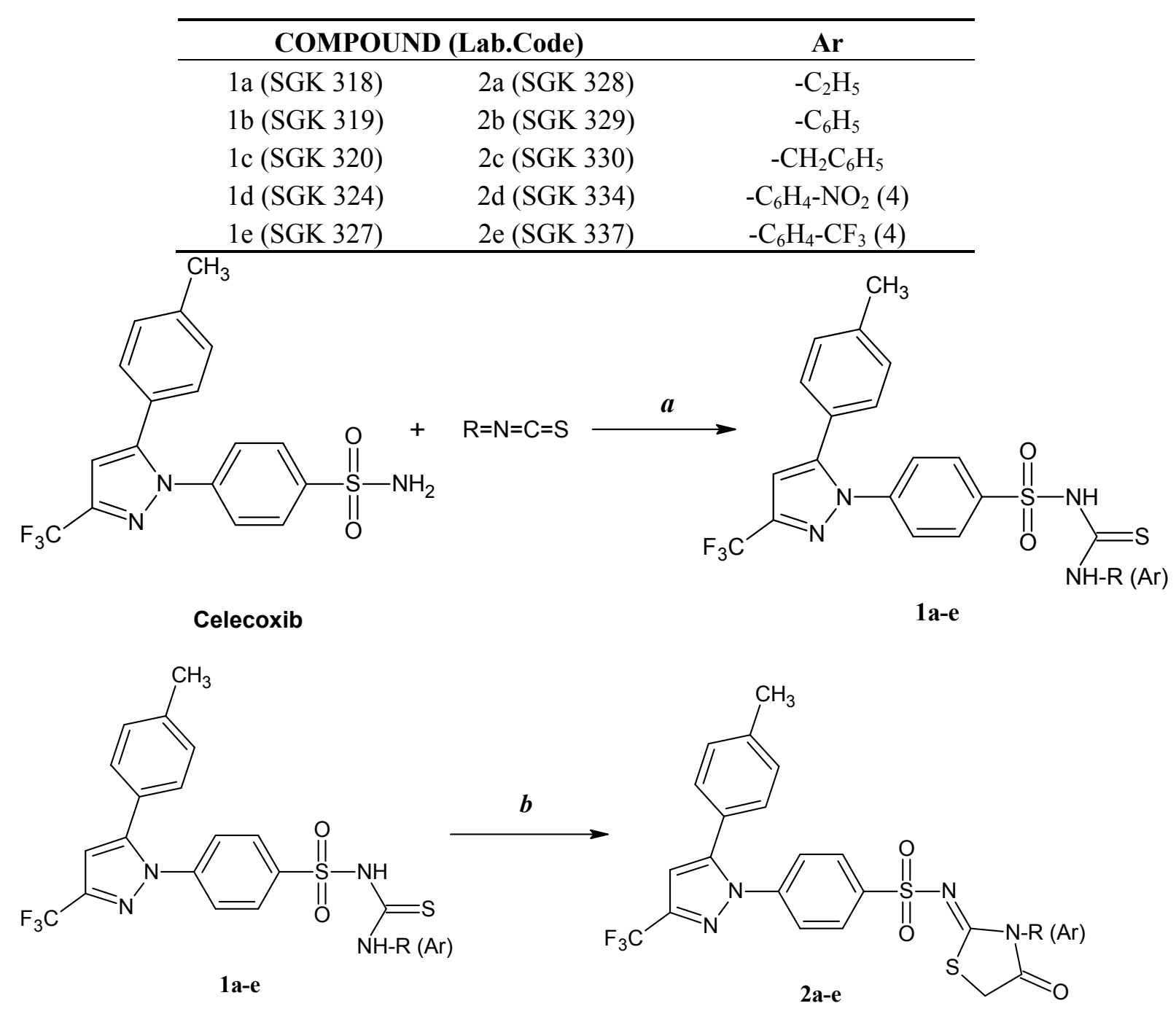

Reagents: (a) dry acetone, anh. $\mathrm{K}_{2} \mathrm{CO}_{3}$; (b) anh. $\mathrm{CH}_{3} \mathrm{COONa}, \mathrm{BrCH}_{2} \mathrm{COOC}_{2} \mathrm{H}_{5}$, dry ethanol. 
The FT-IR spectra of the sulfonylthiourea products $1 \mathbf{a}-\mathbf{e}$ showed characteristic absorption bands in the thiocarbonyl frequency region at $1122-1134 \mathrm{~cm}^{-1}$ and these data is in agreement with the suggested structures. The ${ }^{1} \mathrm{H}-\mathrm{NMR}$ spectra of 1a-e displayed singlets at $9.08-10.75 \mathrm{ppm}$ for the $-\mathrm{SO}_{2} \mathrm{NH}$ group. The ${ }^{1} \mathrm{H}-\mathrm{NMR}$ spectrum of compound $\mathbf{1 b}$, taken as a typical example of the prepared series, revealed a singlet corresponding to the $-\mathrm{SH}$ proton at $4.20 \mathrm{ppm}$ and $-\mathrm{NH}$ peaks were not detected. The thione tautomeric form was converted into the thiol tautomer due to the use of DMSO- $\mathrm{d}_{6}$. Strong deshielding of this thiol proton can be explained by hydrogen bond formation. The $-\mathrm{SO}_{2} \mathrm{~N} \underline{\mathrm{H}}$ proton of $1 \mathrm{c}$ was observed to exchange with deuterium in DMSO- $\mathrm{d}_{6}$. Also, the signals of the $-\mathrm{CH}_{2}$ - group appear as two doublets at 4.33 and $4.62 \mathrm{ppm}$ and may result from hindered rotation of the $\mathrm{NH}-\mathrm{CH}_{2}-$ bond in DMSO- $\mathrm{d}_{6}$ solution. A signal at 3.61-4.96 ppm due to $-\mathrm{S}-\mathrm{CH}_{2}-$ confirms the formation of the thiazolidinone ring. The FT-IR spectra of the 4-thiazolidinone derivatives $\mathbf{2 a}-\mathbf{e}$ were studied and were in agreement with the required structures.

\subsection{Biological Activity}

\subsubsection{Anti-inflammatory Activity, Carrageenan-Induced Oedema}

At first, the substances were screened for anti-inflammatory activity at $100 \mathrm{mg} / \mathrm{kg}, \mathrm{p} . \mathrm{o}$. dose. The compounds having more than $15 \%$ effectiveness in relieving symptoms, even though some of them are not statistically significant, were considered both for further evaluation of anti-inflammatory activity in two different dose levels (50 and $200 \mathrm{mg} / \mathrm{kg}$ ) and for screening of their analgesic activities at the dose of $100 \mathrm{mg} / \mathrm{kg}$. Besides, these compounds were also evaluated for their gastric toxicity by determining the lipid peroxidation level and ulcer scores in stomachs. We used celecoxib as a reference compound, because the synthesized compounds were derived from celecoxib. We wanted to investigate the influence of molecular modification on biological activity.

All pharmacological activity results have been summarized in Tables 1 and 2. As seen in Table 1, the compounds $1 \mathbf{1}, \mathbf{1 d}, \mathbf{1 e}$ and $\mathbf{2 d}$ possessed moderate-to-good anti-inflammatory activity at all doses in all of the measurement intervals. Good inhibition of the second phase of carrageenan-induced oedema was observed for the compounds 1a and 1d, suggesting that they interfere with prostaglandin synthesis. Compounds 1e and 2e exhibited significant activity, especially at $50 \mathrm{mg} / \mathrm{kg}$ doses in the first phase.

Since the carrageenan oedema has been used in the development of indomethacie, many researchers have adapted this procedure for screening potential anti-inflammatory compounds. Carrageenaninduced oedema is a nonspecific inflammation maintained by the release of histamine, 5-hydroxytryptamine, kinins and later by prostaglandins [21]. The inhibitory effect of NSAIDs, such as indomethacin, is usually weak in the first phase (1-2 h), in contrast with their strong inhibition in the second phase (3-4 h) [22]. Furthermore, many studies have demonstrated that the massive production of nitric oxide (NO) and PGE2 via pro-inflammatory proteins inducible nitric oxide synthase (iNOS) and COX-2, respectively, plays an important pathophysiological role in the development of carrageenan-induced thermal hyperalgesia and paw edema [23,24].

There was a noticeable anti-inflammatory activity at $50 \mathrm{mg} / \mathrm{kg}$ dose only in compounds $\mathbf{1 a}$, 1e and $\mathbf{2 d}$. Especially, the compound 2d showed the most remarkable inhibition $(48.9 \%, p<0.01)$ at $50 \mathrm{mg} / \mathrm{kg}$ dose. 
Moreover, the activity of the compound $\mathbf{2 d}$ at $50 \mathrm{mg} / \mathrm{kg}$ dose was more prominent than the ones seen with other doses. It has attracted attention with almost equivalent activity to celecoxib.

Table 1. Dose-dependent anti-inflammatory effects of the compounds against carrageenan-induced hind paw edema model in mice in different doses.

\begin{tabular}{|c|c|c|c|c|c|}
\hline \multirow[t]{2}{*}{ Compounds } & \multirow{2}{*}{$\begin{array}{c}\text { Dose } \\
\text { mg/kg } \\
\text { (per os) }\end{array}$} & \multicolumn{4}{|c|}{$\begin{array}{c}\text { Swelling in thickness }\left(\times 10^{-2} \mathrm{~mm}\right) \pm \text { SEM } \\
\text { (percent inhibitory activity) }\end{array}$} \\
\hline & & $90 \mathrm{~min}$ & $180 \mathrm{~min}$ & 270 min & $360 \mathrm{~min}$ \\
\hline \multicolumn{6}{|l|}{ Control } \\
\hline & & $72.0 \pm 6.6$ & $92.0 \pm 8.1$ & $121.0 \pm 9.8$ & $129.0 \pm 7.8$ \\
\hline \multirow[t]{3}{*}{$1 \mathbf{a}$} & 100 & $58.1 \pm 6.6(19.4)$ & $72.9 \pm 11.9(19.7)$ & $72.7 \pm 16.7(39.5)$ & $77.9 \pm 11.7 * *(39.7)$ \\
\hline & 50 & $70.0 \pm 6.5(2.7)$ & $72.0 \pm 5.1(21.7)$ & $90.0 \pm 9.3 *(25.6)$ & $100.0 \pm 6.5 *(22.4)$ \\
\hline & 200 & $54.6 \pm 7.9(25.0)$ & $74.2 \pm 8.2(19.3)$ & $117.5 \pm 9.8(2.9)$ & $97.4 \pm 5.6 * *(24.5)$ \\
\hline \multirow[t]{3}{*}{ 1d } & 100 & $95.9 \pm 10.2$ & $100.6 \pm 5.8(18.3)$ & $110.7 \pm 11.0(8.5)$ & $88.7 \pm 9.3 *(31.2)$ \\
\hline & 50 & $70.0 \pm 4.7(2.7)$ & $77.0 \pm 2.0(16.3)$ & $112.0 \pm 7.3(7.4)$ & $125.0 \pm 5.9(3.1)$ \\
\hline & 200 & $45.9 \pm 10.9(36.2)$ & $65.3 \pm 6.4(29.0)$ & $98.2 \pm 9.8(19.0)$ & $91.0 \pm 3.3 * *(29.5)$ \\
\hline \multirow[t]{3}{*}{ 1e } & 100 & $88.4 \pm 2.6$ & $83.9 \pm 3.4(8.8)$ & $88.7 \pm 11.4(26.7)$ & $83.4 \pm 9.6 * *(35.4)$ \\
\hline & 50 & $47.0 \pm 3.3 *(34.7)$ & $57.0 \pm 6.2 * *(38.0)$ & $92.0 \pm 1.2 *(23.9)$ & $106.0 \pm 6.7(17.8)$ \\
\hline & 200 & $76.9 \pm 5.7$ & $83.0 \pm 6.8$ & $110.5 \pm 7.5$ & $103.7 \pm 5.2 *(19.6)$ \\
\hline \multirow[t]{3}{*}{$2 c$} & 100 & $83.4 \pm 8.7$ & $90.6 \pm 11.7$ & $91.7 \pm 16.7(24.2)$ & $118.2 \pm 7.1(8.3)$ \\
\hline & 50 & $65.0 \pm 6.1(9.7)$ & $74.0 \pm 8.8(19.5)$ & $95.0 \pm 10.0(21.4)$ & $110.0 \pm 7.1(14.7)$ \\
\hline & 200 & $69.5 \pm 8.3(3.4)$ & $75.6 \pm 8.3(17.8)$ & $133.2 \pm 14.3$ & $120.1 \pm 5.3(6.9)$ \\
\hline \multirow[t]{3}{*}{$2 d$} & 100 & $73.2 \pm 11.1$ & $100.6 \pm 5.8$ & $98.2 \pm 16.7(21.6)$ & $120.9 \pm 9.3(6.3)$ \\
\hline & 50 & $47.0 \pm 3.3 *(34.7)$ & $47.0 \pm 3.7 * *(48.9)$ & $89.0 \pm 6.5 *(26.4)$ & $110.0 \pm 6.7(14.7)$ \\
\hline & 200 & $80.6 \pm 9.4$ & $86.0 \pm 9.4(6.5)$ & $121.0 \pm 12 . .8$ & $108.6 \pm 5.6(15.8)$ \\
\hline Celecoxib & 25 & $57.0 \pm 6.9(20.8)$ & $42.0 \pm 3.3 * *(54.3)$ & $94.0 \pm 10.4(22.3)$ & $103.0 \pm 7.5 *(20.1)$ \\
\hline
\end{tabular}

\subsubsection{Analgesic Activity}

The analgesic activities of compounds $1 \mathbf{1 a}, \mathbf{1 d}, \mathbf{1 e}, \mathbf{2 c}$ and $\mathbf{2 d}$ were tested according the Koster test compared to celecoxib and aspirin (ASA) (Table 2). In this study, the synthesized compounds were obtained from celecoxib and there were no guarantee that our compounds would have no ulcerogenic potential. Therefore, we used ASA as a positive control for ulcerogenic activity whereas celecoxib were also used as negative control.

The analgesic activity of the compounds was studied using the acetic acid-induced writhing test in mice and expressed as "mean increase in latency after drug administration \pm SEM" relative to control and percentage inhibition in writhing reflex. Although the compounds 2c and 2d showed some activity, it is not statistically significant. Among the compounds, $N$-(ethylcarbamothioyl)-4-[5-(4methylphenyl)-3-(trifluoromethyl)-1H-pyrazol-1-yl] benzenesulfonamide (1a) attracted attention with higher analgesic activity than celecoxib with a percentage inhibition valus of 67.8 at $100 \mathrm{mg} / \mathrm{kg}$ dose level. These observations allow us to conclude that compounds having aliphatic sulfonylthiourea groups possessed higher activity than compounds having aromatic sulfonylthiourea groups and sulfonyliminothiazolidine-4-ones. 
Table 2. Analgesic effects of the test compounds at a $100 \mathrm{mg} / \mathrm{kg}$ dose, against acetic acid-induced abdominal constriction test, ulcer score and the lipid peroxidation levels in stomach of mice.

\begin{tabular}{cccc}
\hline Compounds & $\begin{array}{c}\text { Writhing test } \\
\text { (Mean } \pm \text { SEM) (\% inh.) }\end{array}$ & $\begin{array}{c}\text { Ulcer score } \\
(\mathbf{2 0 0} \mathbf{~ m g} / \mathbf{k g})\end{array}$ & $\begin{array}{c}\text { Lipid peroxidation } \\
\text { (nmol TBARS/g wet weight) }\end{array}$ \\
\hline Control & $17.4 \pm 3.7$ & $0 / 5$ & $387.7 \pm 27.9$ \\
Celecoxib $(25 \mathrm{mg} / \mathrm{kg})$ & $8.0 \pm 1.3(54) *$ & $0 / 5$ & $417.8 \pm 23.3$ \\
ASA $(200 \mathrm{mg} / \mathrm{kg})$ & $4.4 \pm 0.9(74.7) * *$ & $3 / 5$ & $436.1 \pm 17.1$ \\
$\mathbf{1 a}$ & $5.6 \pm 0.9(67.8) * *$ & $0 / 5$ & $387.7 \pm 12.8$ \\
$\mathbf{1 d}$ & $14.0 \pm 3.0(19.5)$ & $0 / 5$ & $429.2 \pm 23.2$ \\
1e & $24.0 \pm 3.0(-37.9)$ & $0 / 5$ & $406.9 \pm 27.0$ \\
2c & $11.8 \pm 1.4(32.2)$ & $0 / 5$ & $330.4 \pm 9.7$ \\
2d & $12.0 \pm 2.6(31)$ & $0 / 5$ & $350.2 \pm 9.9$ \\
\hline \multicolumn{4}{c}{}
\end{tabular}

\subsubsection{Acute Ulcerogenesis}

The compounds, which were screened for analgesic activity, were further screened for their acute ulcerogenic risk. All tested compounds were found to be safer as gastric lesion risks at high dose (200 mg/kg. p.o) when compared to aspirin (Table 2). Morever, gastric safety of celecoxib has been identified ast not changed by molecular modification in this study.

\subsubsection{Acute Toxicity}

None of the test compounds used in the pharmacologic study produced lethal effects and did not induce any significant behavioral modification at the employed doses during the observation period.

\subsubsection{Antioxidant Activity, Lipid Peroxidation in Stomach}

It is well established that reactive oxygen species have a decisive role in inflammatory conditions [8]. It has also been reported that oxidative stress is important for gastrointestinal ulceration [8,25]. The compounds having antioxidant activity besides anti-inflammatory/analgesic activity may offer a viable route to safer anti-inflammatory/analgesic agents. The obtained lipid peroxidation (LPO) values revealed that the ulcerogenic effect of the compounds were appreciably less than ASA.

\subsubsection{Tissue Damage/Antioxidant Effects of Compound 1a in Various Tissues}

The antioxidant/ toxic effects of compound 1a, the best analgesic activity observed were examined by using some of oxidative stress parameters on other tissues except for the stomach. The aim of this study was to evaluate the effect of the compound 1a, which was orally administered to mice at doses of $100 \mathrm{mg} / \mathrm{kg}$ and $200 \mathrm{mg} / \mathrm{kg}$, in two different doses on LPO, glutathione (GSH) levels, myeloperoxidase (MPO) and superoxide dismutase (SOD) activities of various tissues (liver, kidney, colon and brain) (Tables 3-6) [26-28]. According to our result, we didn't find any differences in oxidative stress parameters between groups $(p>0.05)$. This study showed that compound 1a has no effects in tissue (liver, kidney, colon and brain) damage. Thus, this compound may safely use as therapeutic agent in the future. 
Table 3. Oxidative stress parameters in liver.

\begin{tabular}{ccccccc}
\hline Parameters & Control & Celecoxib & $\begin{array}{c}\text { Comp. 1a } \\
\mathbf{( 1 0 0 ~} \mathbf{~ m g} / \mathbf{k g})\end{array}$ & Control & Celecoxib & $\begin{array}{c}\text { Comp. 1a } \\
(\mathbf{2 0 0} \mathbf{~ m g} / \mathbf{k g})\end{array}$ \\
\hline $\begin{array}{c}\text { LPO } \\
(\mathrm{nmol} / \mathrm{gtissue})\end{array}$ & $8.80 \pm 0.82$ & $9.56 \pm 1.80$ & $9.78 \pm 1.30$ & $15.28 \pm 2.06$ & $11.74 \pm 2.25$ & $13.72 \pm 3.05$ \\
$\mathrm{MPO}(\mathrm{U} / \mathrm{gtissue})$ & $0.54 \pm 0.31$ & $0.63 \pm 0.30$ & $0.50 \pm 0.28$ & $0.21 \pm 0.01$ & $0.19 \pm 0.06$ & $0.15 \pm 0.08$ \\
$\begin{array}{c}\text { GSH } \\
(\mu \mathrm{mol} / \mathrm{g} \text { tissue })\end{array}$ & $24.06 \pm 4.07$ & $20.58 \pm 4.25$ & $22.68 \pm 1.20$ & $21.80 \pm 6.40$ & $22.14 \pm 1.04$ & $24.58 \pm 4.47$ \\
SOD (U/g tissue) & $18.67 \pm 14.70$ & $22.78 \pm 14.45$ & $21.15 \pm 9.98$ & $10.36 \pm 5.22$ & $13.60 \pm 11.98$ & $11.72 \pm 5.10$ \\
\hline
\end{tabular}

Table 4. Oxidative stress parameters in kidney.

\begin{tabular}{ccccccc}
\hline Parameters & Control & Celecoxib & $\begin{array}{c}\text { Comp. 1a } \\
(\mathbf{1 0 0} \mathbf{~ m g} / \mathbf{k g})\end{array}$ & Control & Celecoxib & $\begin{array}{c}\text { Comp. 1a } \\
(\mathbf{2 0 0} \mathbf{~ m g} / \mathbf{k g})\end{array}$ \\
\hline $\begin{array}{c}\text { LPO } \\
(\mathrm{nmol} / \mathrm{g} \text { tissue })\end{array}$ & $13.42 \pm 3.43$ & $11.12 \pm 2.41$ & $10.96 \pm 2.01$ & $15.18 \pm 2.15$ & $11.30 \pm 2.52$ & $12.56 \pm 2.96$ \\
$\mathrm{MPO}(\mathrm{U} / \mathrm{g}$ tissue $)$ & $4.97 \pm 1.87$ & $3.36 \pm 1.57$ & $3.18 \pm 2.66$ & $3.59 \pm 1.37$ & $4.75 \pm 1.59$ & $4.59 \pm 1.01$ \\
$\begin{array}{c}\text { GSH } \\
(\mu \mathrm{mol} / \mathrm{g} \text { tissue })\end{array}$ & $20.76 \pm 5.60$ & $22.24 \pm 4.17$ & $17.02 \pm 5.23$ & $18.77 \pm 5.52$ & $21.68 \pm 5.56$ & $18.26 \pm 3.28$ \\
$\mathrm{SOD}(\mathrm{U} / \mathrm{g}$ tissue $)$ & $15.09 \pm 5.94$ & $17.79 \pm 7.47$ & $20.26 \pm 8.71$ & $14.14 \pm 8.81$ & $16.83 \pm 9.71$ & $15.37 \pm 7.33$ \\
\hline
\end{tabular}

Table 5. Oxidative stress parameters in colon.

\begin{tabular}{ccccccc}
\hline Parameters & Control & Celecoxib & $\begin{array}{c}\text { Comp. 1a } \\
(\mathbf{1 0 0} \mathbf{~ m g} / \mathbf{k g})\end{array}$ & Control & Celecoxib & $\begin{array}{c}\text { Comp. 1a } \\
(\mathbf{2 0 0} \mathbf{~ m g} / \mathbf{k g})\end{array}$ \\
\hline $\begin{array}{c}\text { LPO } \\
(\mathrm{nmol} / \mathrm{g} \text { tissue })\end{array}$ & $7.25 \pm 0.27$ & $7.12 \pm 0.26$ & $8.66 \pm 2.23$ & $8.71 \pm 1.86$ & $10.48 \pm 2.69$ & $11.04 \pm 2.11$ \\
$\mathrm{MPO}(\mathrm{U} / \mathrm{gtissue})$ & $0.28 \pm 0.19$ & $0.52 \pm 0.26$ & $0.27 \pm 0.13$ & $0.32 \pm 0.10$ & $0.46 \pm 0.26$ & $0.38 \pm 0.14$ \\
$\begin{array}{c}\text { GSH } \\
(\mu \mathrm{mol} / \mathrm{g} \text { tissue })\end{array}$ & $22.98 \pm 2.95$ & $28.06 \pm 1.45$ & $27.22 \pm 2.41$ & $26.42 \pm 7.48$ & $26.42 \pm 3.46$ & $25.16 \pm 2.76$ \\
$\mathrm{SOD}(\mathrm{U} / \mathrm{g}$ tissue $)$ & $20.72 \pm 7.28$ & $16.85 \pm 5.24$ & $16.56 \pm 4.13$ & $22.41 \pm 6.42$ & $19.04 \pm 5.60$ & $21.17 \pm 4.15$ \\
\hline
\end{tabular}

Table 6. Oxidative stress parameters in brain.

\begin{tabular}{ccccccc}
\hline Parameters & Control & Celecoxib & $\begin{array}{c}\text { Comp. 1a } \\
(\mathbf{1 0 0} \mathbf{~ m g} / \mathbf{k g})\end{array}$ & Control & Celecoxib & $\begin{array}{c}\text { Comp. 1a } \\
(\mathbf{2 0 0} \mathbf{~ m g} / \mathbf{k g})\end{array}$ \\
\hline LPO (nmol/g tissue) & $7.53 \pm 0.58$ & $8.18 \pm 2.16$ & $8.36 \pm 2.61$ & $8.42 \pm 1.74$ & $8.26 \pm 1.01$ & $9.40 \pm 2.08$ \\
MPO (U/gtissue) & $0.33 \pm 0.21$ & $0.60 \pm 0.23$ & $0.73 \pm 0.32$ & $1.42 \pm 0.37$ & $1.48 \pm 0.46$ & $1.95 \pm 0.60$ \\
GSH & $18.88 \pm 4.13$ & $22.36 \pm 2.45$ & $18.7 \pm 5.52$ & $16.26 \pm 2.81$ & $20.2 \pm 3.26$ & $18.74 \pm 3.03$ \\
$\begin{array}{c}(\mu \mathrm{mol} / \mathrm{g} \text { tissue) } \\
\text { SOD (U/g tissue) }\end{array}$ & $20.84 \pm 4.83$ & $24.84 \pm 10.65$ & $19.17 \pm 7.41$ & $20.19 \pm 4.86$ & $20.41 \pm 13.73$ & $19.22 \pm 10.76$ \\
\hline
\end{tabular}

\subsubsection{Anticancer Activity}

The selected compound $N$-(ethylcarbamothioyl)-4-[5-(4-methylphenyl)-3-(trifluoromethyl)-1Hpyrazol-1-yl]benzenesulfonamide (1a) was screened by the National Institutes of Health (NIH) for anticancer activity against 60 human tumor cell lines. Most of the compounds in the series of structures submitted include one or more functional groups that have been found troublesome to the development 
of successful drug candidates. In addition, the selection criteria guidance available at the following DTP web site: http://www.dtp.nci.nih.gov/docs/misc/common_files/guidelines.html [29]. For NCI criteria, compounds, which reduce the growth of any one of the cell lines to approximately $32 \%$ or less, are passed on for evaluation in the full panel of cell lines over a 5-log dose range. Compound 1a exhibited significant cytotoxicity in melonoma Malm-3M cells (150.58\%).

\subsubsection{Effect on HCV NS5B Polymerase Enzyme Inhibition}

The ability of the compounds to inhibit HCV NS5B RdRp activity was investigated in vitro employing poly $\mathrm{rA}-\mathrm{U}_{12}$ template-primer as described in the Experimental section [30-32]. The compounds 1a-e and 2a-e were reconstituted in DMSO as $50 \mathrm{mM}$ stocks, and serially diluted in DMSO to obtain working stocks. Wedelolactone, a known inhibitor of HCV NS5B activity [32], was employed as a reference compound. Preliminary screening was carried out at $100 \mu \mathrm{M}$ to identify a wider range of compounds. Celecoxib, the parent molecule, included in this investigation for comparison with its derivatives, exhibited the lowest activity against NS5B of $\sim 10 \%$. All other compounds except 2a and 2e exhibited varying degrees of inhibition ranging from $\sim 19 \%$ to $83 \%$ at 100 $\mu \mathrm{M}$ concentration (Table 7). Of these, compounds $\mathbf{1 c}$ and $\mathbf{1 d}$ exhibited modest inhibition, with $\mathrm{IC}_{50}$ values of $\sim 36 \mu \mathrm{M}$ and $46 \mu \mathrm{M}$.

Table 7. Anti-HCV NS5B RdRp activity of celecoxib derivatives in vitro *.

\begin{tabular}{cccc}
\hline Compound & $\mathbf{A r} / \mathbf{R}$ & $\begin{array}{c}\text { Anti-NS5B Activity } \\
(\mathbf{\%} \mathbf{I n h} ., \mathbf{1 0 0} \boldsymbol{\mu M})\end{array}$ & $\mathbf{I C}_{\mathbf{5 0}}(\boldsymbol{\mu} \mathbf{M})$ \\
\hline $1 \mathrm{a}$ & $-\mathrm{C}_{2} \mathrm{H}_{5}$ & 49.4 & N.D. \\
$1 \mathrm{~b}$ & $-\mathrm{C}_{6} \mathrm{H}_{5}$ & 53.5 & N.D. \\
$1 \mathrm{c}$ & $-\mathrm{CH}_{2} \mathrm{C}_{6} \mathrm{H}_{5}$ & 82.3 & $36.2 \pm 1.2$ \\
$1 \mathrm{~d}$ & $-\mathrm{C}_{6} \mathrm{H}_{4}-\left(4-\mathrm{NO}_{2}\right)$ & 68 & $45.5 \pm 1.2$ \\
$1 \mathrm{e}$ & $-\mathrm{C}_{6} \mathrm{H}_{4}-\left(4-\mathrm{CF}_{3}\right)$ & 14.6 & N.D. \\
$2 \mathrm{a}$ & $-\mathrm{C}_{2} \mathrm{H}_{5}$ & 8.2 & N.D. \\
$2 \mathrm{~b}$ & $-\mathrm{C}_{6} \mathrm{H}_{5}$ & N.D. & N.D. \\
$2 \mathrm{c}$ & $-\mathrm{CH}_{2} \mathrm{C}_{6} \mathrm{H}_{5}$ & 19.4 & N.D. \\
$2 \mathrm{~d}$ & $-\mathrm{C}_{6} \mathrm{H}_{4}-\left(4-\mathrm{NO}_{2}\right)$ & 31.3 & N.D. \\
$2 \mathrm{e}$ & $-\mathrm{C}_{6} \mathrm{H}_{4}-\left(4-\mathrm{CF}_{3}\right)$ & 9.4 & N.D. \\
Celecoxib & & 9.5 & \\
\hline
\end{tabular}

\footnotetext{
* Percent inhibition was determined at $100 \mu \mathrm{M}$ concentration of the indicated compound and represents an average of at least two independent measurements in duplicate. The $\mathrm{IC}_{50}$ values of the compounds were determined from dose-response curves employing 8-12 concentrations of each compound in duplicate in two independent experiments. Curves were fitted to data points using nonlinear regression analysis and $\mathrm{IC}_{50}$ values were interpolated from the resulting curves using GraphPad Prism 3.03 software. (N.D. = not determined.).
}

To investigate the potential binding mode of celecoxib derivatives to HCV NS5B, we performed molecular modeling studies with the most potent compounds 1c and 1d using the Glide docking software, as previously described [32]. To evaluate which of the five allosteric pockets these inhibitors tightly bind to, docking experiments were conducted against each of the five reported NS5B allosteric pockets such as TP-I (PDB ID: 2XWY) [33], TP-II (PDB ID: 3FRZ) [34], palm pocket (PP)-I (PDB 
ID: 3TYV) [35], PP-II (PDB ID: 3FQL) [36] and PP-III, that significantly overlaps with pocket PP-II (large grid box created around HCV-796 coordinates to obtain docking pose at pocket PP-III). The binding energy (XP-Glide score) of compound $\mathbf{1 c}$ and $\mathbf{1 d}$ was found to be -6.98 and $-6.57,-7.70$ and $-6.50,-9.45$ and $-9.44,-5.60$ and $-5.75,-5.74$ and -5.45 , at TP-I, TP-II, PP-I, PP-II and PP-III, respectively. The relatively more negative Gscore in PP-I versus other pockets indicated a better fit of compounds 1c and 1d in PP-I, thus suggesting that PP-I may be the potential binding site for celecoxib derivatives.

To gain insight into the mechanism of inhibition by celecoxib derivatives, we analyzed the interactions of the docked conformation of potent compound 1c within PP-I of NS5B (Figure 2). The phenyl ring of the benzyl substituent appeared to establish cation-pi interactions with the positively charged $\varepsilon-\mathrm{NH}_{2}$ and guanidinium group of Lys141 and Arg158, respectively. Both the - NH groups of thiourea moiety form water-mediated hydrogen bonding interactions with the backbone carbonyl oxygen atom of Asn316 (-NH---OH $\mathrm{OH}_{2}-874,1.7 \AA$; -NH---OH The phenyl ring attached to the sulfonamide group is stabilized by hydrophobic interactions with the side chain of Tyr448. The tolylpyrazole moiety is extensively stabilized by hydrophobic interactions with the side chains of Met414, Tyr415, Ile447 and Tyr448. The trifluoromethyl group forms hydrogen bond with the side chain hydroxyl group of Ser368 (-F---HO-Ser368, $1.8 \AA$ ) in addition to hydrophobic interaction with Leu384.

Figure 2. XP-Glide predicted binding mode of compound 1c within palm pocket-I of NS5B. Important amino acids contacting compound 1c are depicted as stick model with the atoms colored as carbon-green, hydrogen—white, nitrogen — blue, oxygen — red and sulfur-yellow. Compound 1c is shown as ball and stick model with the same color scheme as above except carbon atoms are represented in cyan and fluoro atoms in green color. The dotted black line indicates hydrogen bonding interaction whereas the dotted red line indicates cation-pi interaction with distances in $\AA$.

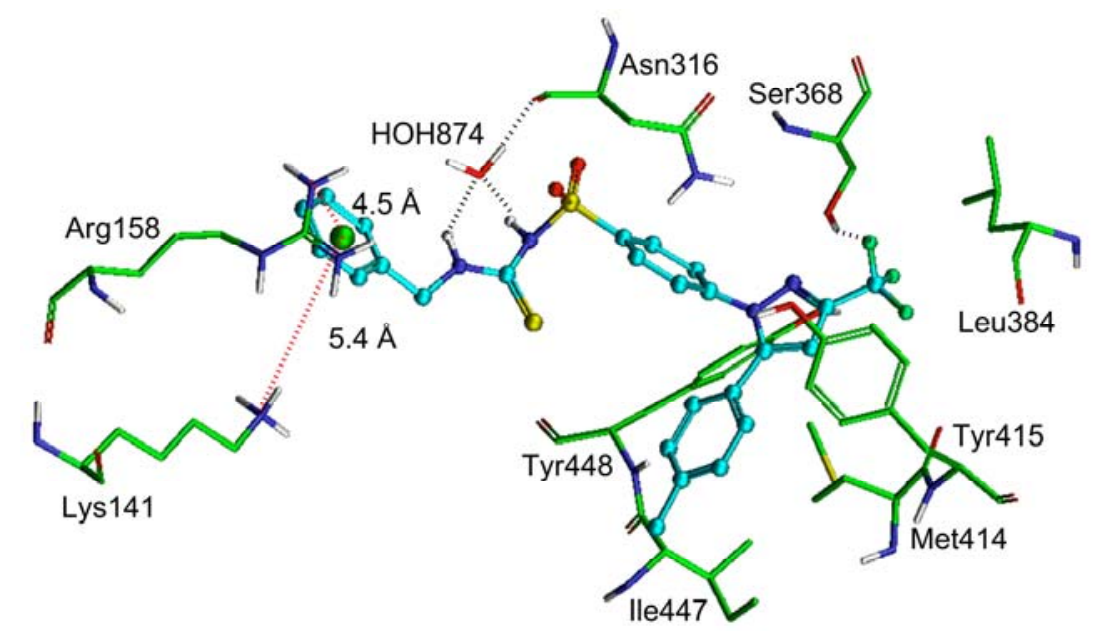




\section{Experimental}

\subsection{General}

All chemical compounds were purchased from Sigma-Aldrich and Fluka. Melting points were taken on Schmelzpunktbestimmer SMP II apparatus and are uncorrected. IR spectra were recorded on a Shimadzu FTIR-8400S instrument. ${ }^{1} \mathrm{H}-\mathrm{NMR}$ and ${ }^{13} \mathrm{C}-\mathrm{NMR}$ spectra were obtained on a Bruker AVANCE 500 and Varian Mercury 400 instrument and chemical shifts were reported in ppm ( $\delta$ ). High resolution electron impact mass spectra were recorded on a Jeol JMS-700 instrument. The microwave assisted reactions were carried out in a household microwave oven (MW 570 manufactured by Kenwood Corporation, maximum power output of $900 \mathrm{~W}$ ). Merck silica gel 60 F254 plates were used for analytical TLC. The purities of the synthesized compounds were checked using thin layer chromatography in petroleum ether $(\mathrm{PE})$ : acetone $\left(\lambda=\mathrm{UV} 254 \mathrm{~nm}, \mathrm{t}=25^{\circ} \mathrm{C}\right)$.

\subsection{Chemistry}

3.2.1. General Procedure for the Synthesis of $N$-(Substituted aryl/alkyl carbamothioyl)-4-[5-(4methylphenyl)-3-(trifluoromethyl)-1H-pyrazol-1-yl]benzenesulfonamides 1a-e

A solution of the appropriate isothiocyanate $(0.00275 \mathrm{~mol})$ in dry acetone $(5 \mathrm{~mL})$ was added to a stirred mixture of celecoxib $(0.0025 \mathrm{~mol})$ and anhydrous potassium carbonate $(0.005 \mathrm{~mol})$ in dry acetone $(20 \mathrm{~mL})$, and the reaction mixture was heated under reflux for 20-25 h. The progress of reaction was monitored by thin layer chromatography. After completion of the reaction, the reaction mixture dissolved in water and acidified with hydrochloric acid $(2 \mathrm{~N})$. The precipitate obtained was filtered off, washed with water, dried and recrystallised twice from ethanol.

$N$-(Ethylcarbamothioyl)-4-[5-(4-methylphenyl)-3-(trifluoromethyl)-1H-pyrazol-1-yl] benzenesulfonamide (1a). White powder, yield 86\%, mp: $215-218{ }^{\circ} \mathrm{C} .{ }^{1} \mathrm{H}-\mathrm{NMR}\left(400 \mathrm{MHz}, \mathrm{DMSO}-\mathrm{d}_{6} / \mathrm{TMS}\right) \delta$ ppm: 1.01 $\left(3 \mathrm{H}, \mathrm{t}, J=7.1 \mathrm{~Hz},-\mathrm{CH}_{2}-\mathrm{CH}_{3}\right) ; 2.31\left(3 \mathrm{H}, \mathrm{s}, \mathrm{Ar}-\mathrm{CH}_{3}\right) ; 3.67\left(2 \mathrm{H}, \mathrm{m},-\mathrm{CH}_{2}-\mathrm{CH}_{3}\right) ; 7.16-8.51(10 \mathrm{H}, \mathrm{m}$, $\mathrm{Ar}-\mathrm{H}$ ve $\left.\mathrm{CSNH}-\mathrm{CH}_{2}-\mathrm{CH}_{3}\right) ; 10.75\left(1 \mathrm{H}, \mathrm{s},-\mathrm{SO}_{2}-\mathrm{NH}\right)$. FT-IR $v_{\max } \cdot\left(\mathrm{cm}^{-1}\right): 3337$ (sulfonylthiourea, -NH); 1345 and $1153\left(\mathrm{SO}_{2}\right) ; 1122(\mathrm{C}=\mathrm{S})$. Anal. for $\mathrm{C}_{20} \mathrm{H}_{19} \mathrm{~F}_{3} \mathrm{~N}_{4} \mathrm{O}_{2} \mathrm{~S}_{2}$ : Found: $\mathrm{C}, 50.52 ; \mathrm{H}, 4.04 ; \mathrm{N}$, 11.77\%. Calc: C, 51.27; H, 4.09; N, 11.96\% . HRMS-EI: $m / z$ calcd for $\mathrm{C}_{20} \mathrm{H}_{19} \mathrm{~F}_{3} \mathrm{~N}_{4} \mathrm{O}_{2} \mathrm{~S}_{2}[\mathrm{M}+\mathrm{H}]^{+}$: 469.0974; found: 469.0974. $\mathrm{R}_{f}$ : 0.73 (PE/Acetone, 5:5);

$N$-(Phenylcarbamothioyl)-4-[5-(4-methylphenyl)-3-(trifluoromethyl)-1H-pyrazol-1-yl] benzenesulfonamide (1b). White powder, yield 70\%, mp: 251-252 ${ }^{\circ} \mathrm{C} .{ }^{1} \mathrm{H}-\mathrm{NMR}\left(500 \mathrm{MHz}, \mathrm{DMSO}-\mathrm{d}_{6} / \mathrm{TMS}\right) \delta$ ppm: 2.29 (3H, s, Ar-CH $\left.\mathbf{H}_{3}\right) ; 4.20(1 \mathrm{H}, \mathrm{s}, \mathrm{SH}$ in thiol form); 6.83-7.83 (14H, m, Ar-H); $9.08(1 \mathrm{H}, \mathrm{s}$, -SO $\mathrm{SO}_{2}$-NH). FT-IR $v_{\max } \cdot\left(\mathrm{cm}^{-1}\right)$ : $3655\left(-\mathrm{OH}, \mathrm{H}_{2} \mathrm{O}\right) ; 3340$ (sulfonylthiourea, -NH); 1319 and 1172 $\left(\mathrm{SO}_{2}\right)$; $1128(\mathrm{C}=\mathrm{S})$. Anal. for $\mathrm{C}_{24} \mathrm{H}_{19} \mathrm{~F}_{3} \mathrm{~N}_{4} \mathrm{O}_{2} \mathrm{~S}_{2}$. $\mathrm{H}_{2} \mathrm{O}$ : Found: $\mathrm{C}$, 54.50; H, 3.52; N, 9.58\%. Calc.: C, 53.92; H, 3.96; N, 10.48\%. Rf: 0.55 (PE/Acetone, 6:4).

$N$-(Benzylcarbamothioyl)-4-[5-(4-methylphenyl)-3-(trifluoromethyl)-1H-pyrazol-1-yl] benzenesulfonamide (1c). White powder, yield 73\%. mp: 237-240 ${ }^{\circ} \mathrm{C} .{ }^{1} \mathrm{H}-\mathrm{NMR}$ (400 MHz DMSO-d 6 /TMS) $\delta$ ppm: 2.30 (3H, s, Ar-CH $)$; $4.33\left(1 \mathrm{H}, \mathrm{d},-\mathrm{NH}-\mathrm{CH}_{2}, J=6.19 \mathrm{~Hz}\right) ; 4.62(1 \mathrm{H}, \mathrm{d},-\mathrm{NH}-\mathrm{CH} 2, J=6.00 \mathrm{~Hz})$; 
7.16-7.78 (15H, m, Ar-H ve CSNH). FT-IR $v_{\max }\left(\mathrm{cm}^{-1}\right): 3612\left(-\mathrm{OH}, \mathrm{H}_{2} \mathrm{O}\right) ; 3360$ (sulfonylthiourea, -NH.); 1377 and $1220\left(\mathrm{SO}_{2}\right) ; 1124(\mathrm{C}=\mathrm{S})$. Anal. for $\mathrm{C}_{25} \mathrm{H}_{21} \mathrm{~F}_{3} \mathrm{~N}_{4} \mathrm{O}_{2} \mathrm{~S}_{2} .3 \mathrm{H}_{2} \mathrm{O}$ : Found: C, 51.72; H, 3.85; N, 9.54\%. Calc.: C, 51.36; H, 4.65; N, 9.58\%. Rf: 0.74 (PE/Acetone, 5:5).

N-[(4-Nitrophenyl)carbamothioyl])-4-[5-(4-methylphenyl)-3-(trifluoromethyl)-1H-pyrazol-1-yl]benzenesulfonamide (1d). Light yellow powder, yield 62\%. mp: $245-248{ }^{\circ} \mathrm{C} .{ }^{1} \mathrm{H}-\mathrm{NMR}(500 \mathrm{MHz}$, DMSO-d $\left._{6} / \mathrm{TMS}\right) \delta$ ppm: $2.29\left(3 \mathrm{H}, \mathrm{s}, \operatorname{Ar}-\mathrm{CH}_{3}\right) ; 7.17-8.07(14 \mathrm{H}, \mathrm{m}, \mathrm{Ar}-\mathrm{H}$ ve CSNH), 9.82 (1H, s, $-\mathrm{SO}_{2}$-NH). FT-IR $v_{\text {max }}\left(\mathrm{cm}^{-1}\right): 3616\left(-\mathrm{OH}, \mathrm{H}_{2} \mathrm{O}\right) ; 3230$ (sulfonylthiourea, -NH.); 1323 and 1166 $\left(\mathrm{SO}_{2}\right) ; 1134(\mathrm{C}=\mathrm{S})$. Anal. Calc. for $\mathrm{C}_{24} \mathrm{H}_{18} \mathrm{~F}_{3} \mathrm{~N}_{5} \mathrm{O}_{4} \mathrm{~S}_{2} .3 \mathrm{H}_{2} \mathrm{O}$ : Found: C, 47.12; H, 3.11; N, 11.38\%. Calc.: C, 46.83; H, 3.93; N, 11.38\%. Rf: 0.48 (PE/Acetone, 5:5).

N-[(4-Trifluoromethylphenyl)carbamothioyl])-4-[5-(4-methylphenyl)-3-(trifluoromethyl)-1H-pyrazol1-yl]benzenesulfonamide (1e). White powder, yield 77\%, mp: 228-231 ${ }^{\circ} \mathrm{C} .{ }^{1} \mathrm{H}-\mathrm{NMR}(400 \mathrm{MHz}$, DMSO-d 6 /TMS) $\delta$ ppm: 2.29 (3H, s, Ar-CH $)$; 7.17-7.94 (14H, m, Ar-H ve CSNH-Ar); 9.50 (1H, s, -SO $\mathrm{SO}_{2}$-NH). FT-IR $v_{\text {max }}\left(\mathrm{cm}^{-1}\right): 3676\left(-\mathrm{OH}, \mathrm{H}_{2} \mathrm{O}\right) ; 3343$ (sulfonylthiourea, -NH.); 1323 and 1232 $\left(\mathrm{SO}_{2}\right) ; 1128(\mathrm{C}=\mathrm{S})$. Anal. for $\mathrm{C}_{25} \mathrm{H}_{18} \mathrm{~F}_{6} \mathrm{~N}_{4} \mathrm{O}_{2} \mathrm{~S}_{2} .2 \mathrm{H}_{2} \mathrm{O}$ : Found $\mathrm{C}$, 48.47; H, 2.91; N, 8.91\%. Calc.: C, 48.38; H, 3.57; N, 9.03\%. Rf: 0.76 (PE/Acetone, 5:5).

3.2.2. Synthesis of $N$-(3-Substituted aryl/alkyl-4-oxo-1,3-thiazolidin-2-ylidene)-4-[5-(4methylphenyl)-3-(trifluoromethyl)-1H-pyrazol-1-yl]benzenesulfonamides 2a-e

\section{Method I (Thermal)}

To a solution of the appropriate sulfonylthiourea derivative $1 \mathbf{a}-\mathbf{e}(0.001 \mathrm{~mol})$ in absolute ethanol $(20 \mathrm{~mL})$ were added ethyl $\alpha$-bromoacetate $(0.0011 \mathrm{~mol})$ and anhydrous sodium acetate $(0.002 \mathrm{~mol})$ and the reaction mixture was heated under reflux for $2-4 \mathrm{~h}$. The precipitated solid was filtered, washed with water, dried and recrystallized twice from ethanol.

\section{Method II (Microwave Assisted Synthesis for 2d and 2e)}

A mixture of the appropriate sulfonylthiourea derivative 1a-e $(0.001 \mathrm{~mol})$ in absolute ethanol $(20 \mathrm{~mL})$, ethyl $\alpha$-bromoacetate $(0.0011 \mathrm{~mol})$ and anhydrous sodium acetate $(0.002 \mathrm{~mol})$ was placed in the microwaveoven and irradiated at $270 \mathrm{~W}$ for $10-15 \mathrm{~min}$. Then, the reaction mixture was left to cool to room temperature. The precipitated solid was filtered, washed with water, dried and recrystallized twice from ethanol.

N-(3-Ethyl-4-oxo-1,3-thiazolidin-2-yldene)-4-[5-(4-methylphenyl)-3-(trifluoromethyl)-1H-pyrazol-1yl]benzenesulfonamide (2a). Brown powder, yield 65\%, mp: $282{ }^{\circ} \mathrm{C} .{ }^{1} \mathrm{H}-\mathrm{NMR}(400 \mathrm{MHz}$, DMSO$\left.\mathrm{d}_{6} / \mathrm{TMS}\right) \delta$ ppm: $0.98-1.10\left(3 \mathrm{H}, \mathrm{m}, \mathrm{N}-\mathrm{CH}_{2}-\mathrm{CH}_{3}\right) ; 2.31\left(3 \mathrm{H}, \mathrm{s}, \mathrm{Ar}-\mathrm{CH}_{3}\right) ; 3.35\left(2 \mathrm{H}, \mathrm{q}, \mathrm{N}-\mathrm{CH}_{2}-\mathrm{CH}_{3}\right)$; $3.61\left(1 \mathrm{H}, \mathrm{d}, \mathrm{S}-\mathrm{CH}_{2}, J=7.2 \mathrm{~Hz}\right) ; 3.79\left(1 \mathrm{H}, \mathrm{d}, \mathrm{S}-\mathrm{CH}_{2}, J=7.2 \mathrm{~Hz}\right) ; 7.16-8.02$ (9H, m, Ar-H).; FT-IR $v_{\text {max }}\left(\mathrm{cm}^{-1}\right): 1708(\mathrm{C}=\mathrm{O}) ; 1334$ and $1234\left(\mathrm{SO}_{2}\right)$. Anal. for $\mathrm{C}_{22} \mathrm{H}_{19} \mathrm{~F}_{3} \mathrm{~N}_{4} \mathrm{O}_{3} \mathrm{~S}_{2}$. Found: $\mathrm{C}, 51.75 ; \mathrm{H}, 3.53$; N, 10.78\%. Calc.: C, 51.96; H, 3.77; N, 11.02\%. HRMS-EI: $m / z$ calcd for $\mathrm{C}_{22} \mathrm{H}_{19} \mathrm{~F}_{3} \mathrm{~N}_{4} \mathrm{O}_{3} \mathrm{~S}_{2}[\mathrm{M}]^{+}$: 508.0845; found: 508.0860. $\mathrm{R}_{f}$ : 0.47 (PE/Acetone, 6:4). 
N-(3-Phenyl-4-oxo-1,3-thiazolidin-2-yldene)-4-[5-(4-methylphenyl)-3-(trifluoromethyl)-1H-pyrazol-1yl]benzenesulfonamide (2b). Light red powder, yield 57\%, mp: $248-249{ }^{\circ} \mathrm{C} .{ }^{1} \mathrm{H}-\mathrm{NMR}(500 \mathrm{MHz}$, $\left.\mathrm{CDCl}_{3} / \mathrm{TMS}\right) \delta$ ppm: $2.38\left(3 \mathrm{H}, \mathrm{s}, \mathrm{Ar}-\mathrm{CH}_{3}\right) ; 4.05\left(2 \mathrm{H}, \mathrm{s}, \mathrm{S}-\mathrm{CH}_{2}\right) ; 6.74-7.83$ (14H, m, Ar-H). FT-IR $v_{\text {max }}\left(\mathrm{cm}^{-1}\right): 3471\left(-\mathrm{OH}, \mathrm{H}_{2} \mathrm{O}\right) ; 1749(\mathrm{C}=\mathrm{O}) ; 1373$ and $1236\left(\mathrm{SO}_{2}\right)$. Anal. for $\mathrm{C}_{26} \mathrm{H}_{19} \mathrm{~F}_{3} \mathrm{~N}_{4} \mathrm{O}_{3} \mathrm{~S}_{2} .3 \mathrm{H}_{2} \mathrm{O}$ : Found: C, 50.63; H, 3.24; N, 9.49\%. Calc.: C, 51.14; H, 4.13; N, 9.18\%. Rf: 0.58 (PE/Acetone, 6:4).

N-(3-Benzyl-4-oxo-1,3-thiazolidin-2-yldene)-4-[5-(4-methylphenyl)-3-(trifluoromethyl)-1H-pyrazol-1yl]benzenesulfonamide (2c). Brown powdes, yield 48\%, mp: $250{ }^{\circ} \mathrm{C} .{ }^{1} \mathrm{H}-\mathrm{NMR}(400 \mathrm{MHz}$, DMSO$\left.\mathrm{d}_{6} / \mathrm{TMS}\right) \delta$ ppm: $2.32\left(3 \mathrm{H}, \mathrm{s}, \mathrm{Ar}-\mathrm{CH}_{3}\right) ; 3.35\left(2 \mathrm{H}, \mathrm{s}, \mathrm{N}-\mathrm{CH} \mathbf{H}_{2}-\mathrm{Ar}\right) ; 4.96\left(2 \mathrm{H}, \mathrm{s}, \mathrm{S}-\mathrm{CH}_{2}\right) ; 7.22-7.91(14 \mathrm{H}$, m, Ar-H). ${ }^{13} \mathrm{C}-\mathrm{NMR} \quad\left(100 \mathrm{MHz}, \quad \mathrm{DMSO}_{6} / \mathrm{TMS}\right) \delta \quad \mathrm{ppm}: 21.49 \quad\left(\mathbf{C H}_{3} \quad-\mathrm{Ar}\right) ; \quad 39.55-40.80$ (thiazolidinone C-5); 47.51 ( $\mathrm{CH}_{2}$-Ar); 107.50 (pyrazole C-4); 125.53 (benzenesulfonyl C-3, C-5); 125.91 (benzenesulfonyl C-2, C-6); $127.00\left(\mathbf{C F}_{3}\right) ; 128.41$ (4-methylphenyl C-2, C-6); 128.66 (benzyl C-2, C-6); 129.17 (benzyl C-3, C-5); 129.48 (4-methylphenyl C-3, C-5); 130.15 (benzyl C-4); 134.94 $\left(\mathbf{C}-\mathrm{SO}_{2}\right.$ ); 135.10 (4-methylphenyl C-1); 139.81 (benzyl C-1); 139.89 (4-methylphenyl C-4); 143.25 (pyrazole C-5); 143.50 (benzenesulfonyl C-4); 146.07 (pyrazole C-3); $165.34(\mathbf{C}=\mathrm{N}) ; 166.35$ $(\mathbf{C}=\mathrm{O}) . \mathrm{FT}-\mathrm{IR} v_{\max }\left(\mathrm{cm}^{-1}\right): 3362\left(-\mathrm{OH}, \mathrm{H}_{2} \mathrm{O}\right) ; 1707(\mathrm{C}=\mathrm{O}) ; 1336$ and $1153\left(\mathrm{SO}_{2}\right)$. Anal. for $\mathrm{C}_{27} \mathrm{H}_{21} \mathrm{~F}_{3} \mathrm{~N}_{4} \mathrm{O}_{3} \mathrm{~S}_{2}$. $\mathrm{H}_{2} \mathrm{O}$ : Found: C, 55.09; H, 3.94; N, 9.52. Calc.: C, 54.56; H, 3.36; N, 9.38\%. Rf: 0.49 (PE/Acetone, 7:3).

N-[3-(4-Nitrophenyl)-4-oxo-1,3-thiazolidin-2-yldene)-4-[5-(4-methylphenyl)-3-(trifluoromethyl)-1Hpyrazol-1-yl]benzenesulfonamide (2d). Light yellow powder, yield 60\%, mp: 270-272 ${ }^{\circ} \mathrm{C}$. ${ }^{1} \mathrm{H}-\mathrm{NMR}$ (400 MHz, DMSO-d 6 /TMS) $\delta$ ppm: $2.38\left(3 \mathrm{H}, \mathrm{s}, \mathrm{Ar}-\mathrm{CH}_{3}\right) ; 4.10\left(2 \mathrm{H}, \mathrm{s}, \mathrm{S}-\mathrm{CH}_{2}\right) ; 6.74-8.32(13 \mathrm{H}, \mathrm{m}$, Ar-H). FT-IR $v_{\text {max }}\left(\mathrm{cm}^{-1}\right): 1749(\mathrm{C}=\mathrm{O}) ; 1348$ and $1147\left(\mathrm{SO}_{2}\right)$. Anal. for $\mathrm{C}_{26} \mathrm{H}_{18} \mathrm{~F}_{3} \mathrm{~N}_{5} \mathrm{O}_{5} \mathrm{~S}_{2}$ : Found: C, 51.08; H, 3.14; N, 11.90\%. Calc.: C, 51.91; H, 3.02; N, 11.64\%. Rf: 0.67 (PE/Acetone, 6:4).

N-[3-(4-Trifluoromethylphenyl)-4-oxo-1,3-thiazolidin-2-yldene)-4-[5-(4-methylphenyl)-3-(trifluoromethyl)-1H-pyrazol-1-yl]benzenesulfonamide (2e). Light red powder, yield 67\%, mp: 234-235 $\left.{ }^{\circ} \mathrm{C}\right) .{ }^{1} \mathrm{H}-\mathrm{NMR}\left(400 \mathrm{MHz}, \mathrm{CDCl}_{3} / \mathrm{TMS}, \delta \mathrm{ppm}\right): 2.38\left(3 \mathrm{H}, \mathrm{s}, \mathrm{Ar}-\mathrm{CH}_{3}\right) ; 4.08\left(2 \mathrm{H}, \mathrm{s}, \mathrm{S}-\mathrm{CH}_{2}\right)$; 6.74-7.85 (13H, m, Ar-H). FT-IR $v_{\max }\left(\mathrm{cm}^{-1}\right): 3471\left(-\mathrm{OH}, \mathrm{H}_{2} \mathrm{O}\right) ; 1743(\mathrm{C}=\mathrm{O}) ; 1327$ and $1147\left(\mathrm{SO}_{2}\right)$. Anal. for $\mathrm{C}_{27} \mathrm{H}_{18} \mathrm{~F}_{6} \mathrm{~N}_{4} \mathrm{O}_{3} \mathrm{~S}_{2} .3 / 2 \mathrm{H}_{2} \mathrm{O}$ : Found: C, 49.47; H, 3.25; N, 8.59\%. Calc.: C, 49.77; H, 3.25; N, $8.59 \%$. $\mathrm{R}_{f}$ : 0.74 (PE/Acetone, 5:5).

\subsection{Biological Activities}

Locally bred balb/c mice of both sexes (30-35 g) were purchased from the animal breeding laboratories of Inonu University (Malatya, Turkey). The animals were fed a standard pellet diet and water ad libitum in a temperature-controlled room. On the day before the treatments, food was withdrawn, but the animals were allowed free access of water. The allocation of animals to different groups was randomized, and the experiments were carried out under blind conditions. Mice used in the present study were cared for in accordance with the directory of the Inonu University Animal Care Unit, which applies the guidelines of the National Institutes of Health on laboratory animal welfare. Procedures involving animals and their care were conducted in conformity with international laws and policies and animal studies accepted by Inonu University Ethical Council (2011/A17). 
Test samples, suspended in a mixture of distilled water and $0.5 \%$ sodium carboxymethyl cellulose (CMC), were given orally to the animals. The control group animals received the same experimental handling as those of the test groups, except that the drug treatment was replaced with appropriate volumes of the dosing vehicle. Either celecoxib [25 mg/kg, body weight (bw)] or ASA (200 mg/kg, bw) in $0.5 \% \mathrm{CMC}$ was used as reference drug.

In the pharmacological studies, in order to avoid wasting mice for inactive compounds, we employed a two-step activity screening model. For the preliminary activity screening, each test group was composed of four mice. All test drugs were administered to mice at doses of $100 \mathrm{mg} / \mathrm{kg} \mathrm{bw}$. Test compounds that possessed more than a $15 \%$ inhibitory effect in any of the measurement ranges were selected for further evaluation of the activity-dose relationship in two different doses (50 and $200 \mathrm{mg} / \mathrm{kg}$ ). Because of the daily changing circumstance, we used another control group for each experiment.

\subsubsection{Anti-inflammatory Activity, Carrageenan-Induced Oedema}

For the determination of the effects on carrageenan-induced paw oedema, the modified method of Kasahara et al. was employed [37]. One hour after the oral administration of either test sample or dosing vehicle, each mouse was injected with a freshly prepared $(0.5 \mathrm{mg} / 25 \mu \mathrm{L})$ suspension of carrageenan (Sigma, St. Louis, MO, USA) in physiological saline (154 mM NaCl). The subplantar tissue of the right hind paw was the injection site for all mice. The contralateral paw (left hind paw) was injected with $25 \mu \mathrm{L}$ saline solution as the internal control. Paw oedema was measured every 90 min for $6 \mathrm{~h}$ after induction of inflammation with a pair of dial thickness gauge callipers (Ozaki Co., Tokyo, Japan). The difference in footpad thickness between the right and left foot indicated the degree of inflammation for each mouse. The change in paw volume, either increase or decrease, was calculated and compared with the control group (dosing vehicle) and analyzed using statistical methods.

Percent inhibitory effects were estimated according to the following equation, where $n$ was the average difference in thickness between the left and right hind paw of the control group and $n^{\prime}$ was that of test group of animals:

$$
\text { Inhibition }(\%)=\left[\left(\mathrm{n}-\mathrm{n}^{\prime}\right) / \mathrm{n}\right] \times 100
$$

Celecoxib was used as a reference compound and administered at $25 \mathrm{mg} / \mathrm{kg}$, bw.

\subsubsection{Analgesic Activity, Koster Test}

One hour after oral administration of test sample, each mouse was injected intraperitoneally with $3 \%(\mathrm{w} / \mathrm{v})$ acetic acid solution $(0.1 \mathrm{~mL} / 10 \mathrm{~g}, \mathrm{bw})$. Starting $5 \mathrm{~min}$ after the acetic acid injection, the number of muscular contractions on mice were counted for a period of $10 \mathrm{~min}$. A significant reduction in the number of writhings by any treatment as compared to the number of writhings in control animals was considered a positive analgesic response. The analgesic activity was expressed as a percentage change from writhing controls. ASA was used as a reference compound and administered at $200 \mathrm{mg} / \mathrm{kg}$ [38]. 


\subsubsection{Gastric-Ulcerogenic Effect}

Eight hours after the treatments of the mice with synthesized compounds at a dose of $100 \mathrm{mg} / \mathrm{kg} \mathrm{bw}$ for analgesic activity tests they were killed under deep ether anaesthesia and their stomachs were removed. Then the stomach of each mouse was opened through great curvature and examined for lesions or bleedings under dissecting microscope.

\subsubsection{Acute Toxicity}

Animals employed in the carrageenan-induced paw oedema experiment were observed for $72 \mathrm{~h}$, and the mortality rate was recorded for each group at the end of the observation period.

3.3.5. Antioxidant Activity, Lipid Peroxidation in Stomach and in Various Tissues (Liver, Kidney, Colon, Brain)

Only the animals which were administered $100 \mathrm{mg} / \mathrm{kg}$ of the test samples were subjected to this experimental process. Eight hours after the analgesic activity experiment, mice were killed under deep ether anesthesia, and their stomachs were removed. The stomach of each mouse was opened through great curvature and was examined for antioxidant activity. Lipid peroxidation was assessed by using the method of Ohkawa et al. [39] as modified by Jammal and Smith [40] and was expressed nmol of thiobarbituric acid (TBA)-reactive substances (TBARS)/g wet weight of tissue. ASA (200 mg/kg) and celecoxib (25 mg/kg) were used as standard drugs. However, LPO, GSH levels, MPO and SOD activities as tissue damage/antioxidant activity markers were measured in various tissues (liver, kidney, colon, brain). The animals who were administered $100 \mathrm{mg} / \mathrm{kg}$ and $200 \mathrm{mg} / \mathrm{kg}$ of the compound 1a and celecoxib $(25 \mathrm{mg} / \mathrm{kg})$ as oral dose were subjected to this experimental process. After agents administered 72 hours, mice were killed and their tissues were removed.

\subsubsection{LPO and GSH Assays}

Tissue samples were homogenized with ice-cold $150 \mathrm{mM} \mathrm{KCl}$ for the determination of LPO and glutathione (GSH) levels. The LPO levels were assayed by monitoring TBARS formation as described above. GSH measurements were performed using a modification of the Ellman procedure [28].

\subsubsection{MPO Assay}

MPO is an enzyme that is found predominantly in the azurophilic granules of polymorphonuclear leukocytes (PMN). Tissue MPO activity is frequently utilized to estimate tissue PMN accumulation in inflamed tissues and correlates significantly with the number of PMN determined histochemically in tissues. MPO activity was measured in tissues in a procedure similar to that documented by Hillegass et al. [26].

\subsubsection{SOD Assay}

SOD is a major antioxidant enzyme found in cells, which protect cells from oxidative stress. SOD activity in the tissue samples was measured according to the previously described method [27]. 


\subsubsection{Statistical Analysis of Data}

Data obtained from animal experiments were expressed as means \pm standard error (SEM). Statistical differences between the treatment and the control group of animals were evaluated by two-tailed Student's $t$ test.

\subsubsection{Cancer Cell Growth Inhibitory Assay}

The methodology of the NCI60 in vitro cancer screen can be found on-line at http://dtp.nci.nih.gov/ branches/btb/ivclsp.html [29] and can be reviewed on their web site.

\subsubsection{NS5B Inhibition Assay}

All synthesized compounds were evaluated for their effect on HCV NS5B RNA dependent RNA polymerase activity in primer dependent elongation assays as previously described [30-32]. Activity of NS5B in the absence of the inhibitor but containing an equivalent amount of DMSO (control reaction) was set at $100 \%$ and that in the presence of the inhibitor was quantified relative to this control.

\section{Molecular Modeling}

Molecular docking computations were carried out on a Dell Precision 470n workstation with the RHEL 4.0 operating system using Glide 5.5 (Schrodinger LLC, New York, NY, USA). 3D Structures of target compounds 1c and 1d were constructed using the fragment dictionary of Maestro 9.0 (Schrodinger LLC) and geometry was optimized by Macromodel program v9.7 (Schrodinger LLC) using the OPLS-AA force field with the steepest descent followed by truncated Newton conjugate gradient protocol. The X-ray crystal structure of NS5B polymerase in complex with MK-3281 (PDB ID: 2XWY) [33], with PF-868554 (PDB ID: 3FRZ) [34] with indole (PDB ID: 3TYV) [35] and with HCV-796 (PDB ID: 3FQL) [36] representing TP-I, TP-II, PP-I and PP-II pockets, respectively, obtained from the RCSB Protein Data Bank (PDB), were used in this study. The protein was optimized for docking using the "Protein Preparation Wizard" and "Prime-Refinement Utility" of Maestro 9.0. The grids were generated using bound inhibitor with the default parameters (the grids for site PP-III were generated using the extended box around HCV-796 bound at PP-II site of NS5B). The detailed extra precision Glide docking parameters were from our previous studies [32].

\section{Conclusions}

The carrageenan-induced paw edema assay in the rat is a test system often used for the testing of NSAIDs and COX-2 inhibitors in acute inflammatory processes. It has been described that the effect of selective COX- 2 inhibitors on carrageenan pleurisy in the rat over a time course ranging from $0-48 \mathrm{~h}$ after injection of the irritant. Generally, after $6 \mathrm{~h}$, the COX-2 inhibitors were without effect whereas dual inhibitors still showed efficacy. This investigation produced great results and showed that efficacy by COX-2 inhibitors drastically depends on the time course of the inflammatory process: onset of inflammation, peak inflammation and resolution. COX-2 inhibitors showed anti-inflammatory activity 
early on during the onset of the inflammatory response coincident with the expression of COX-2 protein [41].

Our results show that compounds $\mathbf{1 a}, \mathbf{1 d}, \mathbf{1 e}, \mathbf{2 d}$ exhibited higher inhibition of oedema formation in the carrageenan-induced rat paw oedema model. It is well documented that oedema produced by carrageenan is a biphasic event. If the inhibition is more effective in the first phase of carrageenaninduced oedema, then the effect is histamine and serotonin mediated. By contrast, if the inhibition is more effective in the second phase, then the effect is prostaglandin mediated [42]. Based on this principle, we speculate that compounds 1a and 1d exhibited anti-inflammatory effect through mechanisms involving suppression of PG. On the other hand, the compounds $1 \mathbf{e}$ and $\mathbf{2 d}$ mediated their effect through down-regulation of serotonin or histamine. However, further studies are warranted to demonstrate this mechanism. The anti-inflammatory activity of celecoxib derivatives was in the range of 19.4 to $36.2 \%$ for 90 min. Further, compound 1a exhibited potent analgesic activity in comparison to the standard drug ASA (acetylsalicylic acid).

This study also reports the analgesic activity and ulcerogenic risk of the new celecoxib derivatives. Few derivatives have been evaluated for potent anti-inflammatory activity devoid of ulcerogenic risk. All tested compounds showed significant reduction in ulcerogenic activity $(0 / 5)$, whereas the standard drug ASA showed high severity index (3/5). The compounds 1a and 2d which exhibited noteworthy anti-inflammatory and analgesic activities, were found relatively safer for ulcerogenic risk than the other compounds. The structure-activity relationships seen for the anti-inflammatory activity were not confirmed for the analgesic activity. The analgesic activity of the reduced derivatives $\mathbf{1 e}$ and $\mathbf{2 d}$ were not significant when compared to the activity obtained by ASA or celecoxib.

Our studies further identified compound 1c as a potential lead for development of anti-HCV NS5B inhibitors. Sulfonylthiourea derivatives were found to be more potent than sulfonyliminothiazolidinones, while celecoxib the parent compound was the least active of all compounds examined in this investigation. In terms of growth inhibition, 1a exhibited negligible cell growth inhibition at $10 \mu \mathrm{M}$ concentration against variety of cell lines.

In conclusion, among the synthesized compounds, $N$-(ethylcarbamothioyl)-4-[5-(4-methylphenyl)3-(trifluoromethyl)-1H-pyrazol-1-yl]benzenesulfonamide (1a), having an ethyl group at the $\mathrm{N}$-position of the sulfonylthiourea structure, showed significant analgesic and promising anti-inflammatory activity with relatively reduced lipid peroxidation, and did not cause tissue damage in liver, kidney, colon or brain compared to control and celecoxib. Thus 1a merits further attention for developing promising anti-inflammatory, analgesic, non-toxic compounds.

\section{Acknowledgments}

We wish to thank the National Cancer Institute for in vitro pharmacological screening. This work was generously supported by the Research Fund of Marmara University, project number: SAG-A-310510-0175 to S.G.K. HCV NS5B inhibition studies were supported by the National Institute of Health Research Grant CA153147 to N.K.-B. The authors are grateful to Jürgen Gross from the Institute of Organic Chemistry, University of Heidelberg, for his generous help on obtaining HR-EI mass spectra of the synthesized compounds. 


\section{References}

1. Vane, J.R. Inhibition of prostaglandin synthesis as a mechanism of action for aspirin-like drugs. Nat. New Biol. 1971, 231, 232-235.

2. Wu, T. Cyclooxygenase-2 in hepatocellular carcinoma. Cancer Treat. Rev. 2006, 32, 28-44.

3. Koga, H.; Sakısaka, S.; Ohishi, M.; Kawaguchi, T.; Taniguchi, E.; Sasatomi, K.; Harada, M.; Kusaba, T.; Tanaka, M.; Kimura, R.; et al. Expression of cyclooxygenase-2 in human hepatocellular carcinoma: Relevance to tumor dedifferentiation. Hepatology 1999, 29, 688-696.

4. Cervello, M.; Montalco, G. Cyclooxygenases in hepatocellular carcinoma. World J. Gastroenterol. 2006, 12, 5113-5121.

5. Pozzi, A.; Yan, X.; Macias-Perez, I.; Wei, S.; Hata, A.N.; Breyer, R.M.; Morrow, J.D.; Capdevila, J.H. Colon carcinoma cell growth is associated with prostaglandin E2/EP4 receptor-evoked ERK activation. J. Biol. Chem. 2004, 279, 29797-29804.

6. Dermond, O.; Rüegg, C. Inhibition of tumor angiogenesis by non-steroidal anti-inflammatory drugs: Emerging mechanisms and therapeutic perspectives. Drug Resist. Updat. 2001, 4, 314-321.

7. Thun, M.J.; Henley, S.J.; Patrono, C. Nonsteroidal anti-inflammatory drugs as anticancer agents: Mechanistic, pharmacologic, and clinical issues. J. Natl. Cancer Inst. 2002, 94, 252-266.

8. Halliwell, B. Drug antioxidant effects. A basis for drug selection? Drugs 1991, 42, 569-605.

9. Djordjevic, V.B. Free radicals in cell biology. Int. Rev. Cytol. 2004, 237, 57-89.

10. Goldenthal, M.J.; Marin-Garcia, J. Mitochondrial signaling pathways: A receiver/integrator organelle. Mol. Cell. Biochem. 2004, 262, 1-16.

11. Pereira, C.V.; Moreira, A.C.; Pereira, S.P.; Machado, N.G.; Carvalho, F.S.; Sardão, V.A.; Oliveira, P.J. Investigating Drug-induced Mitochondrial Toxicity: A Biosensor to Increase Drug Safety? Curr. Drug Saf. 2009, 4, 34-54.

12. Rostom, S.A.; Shalaby, M.A.; El-Demellawy, M.A. Polysubstituted pyrazoles, part 5. Synthesis of new 1-(4-chlorophenyl)-4-hydroxy-1H-pyrazole-3-carboxylic acid hydrazide analogs and some derived ring systems. A novel class of potential antitumor and anti-HCV agents. Eur. J. Med. Chem. 2003, 38, 959-974.

13. Riyadh, S.M.; Farghaly, T.A.; Abdallah, M.A.; Abdalla, M.M.; Abd El-Aziz, M.R. New pyrazoles incorporating pyrazolylpyrazole moiety: Synthesis, anti-HCV and antitumor activity. Eur. J. Med. Chem. 2010, 45, 1042-1050.

14. Popovici-Muller, J.; Shipps, G.W., Jr.; Rosner, K.E.; Deng, Y.; Wang, T.; Curran, P.J.; Brown, M.A.; Siddiqui, M.A.; Cooper, A.B.; Duca, J.; et al. Pyrazolo[1,5-a]pyrimidine-based inhibitors of HCV polymerase. Bioorg. Med. Chem. 2009, 19, 6331-6336.

15. Farghaly, T.A.; Abass, I.M.; Abdalla, M.M.; Mahgoub, R.O.A. Synthesis and pharmacological activities of fused pyrimidinones. World J. Chem. 2011, 6, 8-18.

16. Okamoto, M.; Sakai, M.; Goto, Y.; Salim, M.T.; Baba, C.; Goto, K.; Watashi, K.; Shimotohno, K.; Baba, M. Anti-bovine viral diarrhoea virus and hepatitis $\mathrm{C}$ virus activity of the cyclooxygenase inhibitor SC-560. Antivir. Chem. Chemother. 2009, 20, 47-54.

17. Bock, J.M.; Menon, S.G.; Sinclair, L.L.; Bedford, N.S.; Goswami, P.C.; Domann F.E.; Trask, D.K. Celecoxib toxicity is cell cycle phase specific. Cancer Res. 2007, 67, 3801-3808. 
18. Kern, M.A.; Schubert, D.S.; Sahi, D.; Schöneweiss, M.M.; Moll, I.; Haugg, A.M.; Dienes, H.P.; Breuhahn, K.; Schirmacher, P. Proapoptotic and antiproliferative potential of selective cyclooxygenase-2 inhibitors in human liver tumor cells. Hepatology 2002, 36, 885-894.

19. Rostom, S.A.F. Synthesis and in vitro antitumor evaluation of some indeno[1,2-c]pyrazol(in)es substituted with sulfonamide, sulfonylurea(-thiourea) pharmacophores, and some derived thiazole ring systems. Bioorg. Med. Chem. 2006, 14, 6475-6485.

20. Bekhit, A.A.; Ashour, H.M.; Abdel Ghany, Y.S.; Bekhit, Ael-D.; Baraka, A. Synthesis and biological evaluation of some thiazolyl and thiadiazolyl derivatives of $1 H$-pyrazole as anti-inflammatory antimicrobial agents. Eur. J. Med. Chem. 2008, 43, 456-463.

21. Tsurumi, K.; Kyuki, K.; Niwa, M.; Kokuba, S.; Fujimura, H. Pharmacological investigations of the new antiinflammatory agent 2-(10,11-dihydro-10-oxodibenzo[b,f]thiepin-2-yl)propionic acid. 1st Communication: Inhibitory effects on rat paw edema. Arzneim. Forsch. 1986, 36, 1796-1800.

22. Gavalas, A.; Kourounakis, L.; Litina, D.; Kourounakis, P. Anti-inflammatory and immuno-modulating effects of the novel agent $\gamma$-(2-aminoethylamino)-2-butyrothienone. Inhibitory effects on mouse paw oedema. Arzneim. Forsch/Drug Res. 1991, 41, 423-426.

23. Nantel, F.; Denis, D.; Gordon, R.; Northey, A.; Cirino, M.; Metters, K.M.; Chan, C.C. Distribution and regulation of cyclooxygenase-2 in carrageenan-induced inflammation. $\mathrm{Br}$. $J$. Pharmacol. 1999, 128, 853-859.

24. Meller, S.T.; Cummings, C.P.; Traub, R.J.; Gebhart, G.F. The role of nitric oxide in the development and maintenance of hyperalgesia produced by intraplantar injection of carrageenan in the rat. Neuroscience 1994, 60, 367-374.

25. Bragt, P.C.; Bansberg, J.I.; Bonta, I.L. Antiinflammatory effects of free radical scavengers and antioxidants: Further support for proinflammatory roles of endogenous hydrogen peroxide and lipid peroxides. Inflammation 1980, 4, 289-299.

26. Hillegas, L.M.; Griswold, D.E.; Brickson, B.; Albrightson-Winslow C. Assessment of myeloperoxidase activity in whole rat kidney. J. Pharmacol. Methods 1990, 24, 285-295.

27. Mylorie, A.A.; Collins, H.; Umbles, C.; Kyle, J. Erythrocyte superoxide dismutase activity and other parameters of copper status in rats ingesting lead acetate. Toxicol. Appl. Pharmacol. 1986, $82,512-520$.

28. Beutler, E. Glutathione in Red Blood Cell Metabolism. In A Manual of Biochemical Methods; Grune \& Stratton: New York, NY, USA, 1975; pp. 112-114.

29. National Cancer Institute. Developmental Therapeutics Program: Screening Services. Selection Guidelines for Small Molecule Structures for Screening. Available from http://dtp.nci.nih.gov/branches/btb/ivclsp.html. (accessed on 25 September 2012).

30. Chen, Y.; Bopda-Waffo, A.; Basu, A.; Krishnan, R.; Silberstein, E.; Taylor, D.R.; Talele, T.T.; Arora, P.; Kaushik-Basu, N. Characterization of aurintricarboxylic acid as a potent hepatitis C virus replicase inhibitor. Antivir. Chem. Chemother. 2009, 20, 19-36.

31. Kaushik-Basu, N.; Bopda-Waffo, A.; Talele, T.T.; Basu, A.; Chen, Y.; Kucukguzel, S.G. 4-Thiazolidinones: A novel class of hepatitis C virus NS5B polymerase inhibitors. Front. Biosci. 2008, 13, 3857-3868. 
32. Kaushik-Basu, N.; Bopda-Waffo, A.; Talele, T.T.; Basu, A.; Costa, P.R.; da Silva, A.J.; Sarafianos, S.G.; Noël, F. Identification and characterization of coumestans as novel HCV NS5B polymerase inhibitors. Nucleic Acids Res. 2008, 36, 1482-1496.

33. Narjes, F.; Crescenzi, B.; Ferrara, M.; Habermann, J.; Colarusso, S.; Ferreira Mdel, R.; Stansfield, I.; Mackay, A.C.; Conte, I.; Ercolani, C; et al. Discovery of (7R)-14-cyclohexyl-7-\{[2(dimethylamino)ethyl](methyl)amino -7,8-dihydro-6H-indolo[1,2-e][1,5]benzoxazocine-11-carboxylic acid (MK-3281), a potent and orally bioavailable finger-loop inhibitor of the hepatitis $\mathrm{C}$ virus NS5B polymerase. J. Med. Chem. 2011, 54, 289-301.

34. Li, H.; Tatlock, J.; Linton, A.; Gonzalez, J.; Jewell, T.; Patel, L.; Ludlum, S.; Drowns, M.; Rahavendran, S.V.; Skor, H.; et al. Discovery of (R)-6-cyclopentyl-6-(2-(2,6-diethylpyridin-4yl)ethyl)-3-((5,7-dimethyl-[1,2,4]triazolo[1,5-a]pyrimidin-2-yl)methyl)-4-hydroxy-5,6-dihydropyran2-one (PF-00868554) as a potent and orally available hepatitis $\mathrm{C}$ virus polymerase inhibitor. J. Med. Chem. 2009, 52, 1255-1258.

35. Chen, K.X.; Vibulbhan, B.; Yang, W.; Sannigrahi, M.; Velazquez, F.; Chan, T.Y.; Venkatraman, S.; Anilkumar, G.N.; Zeng, Q.; Bennet, F.; et al. Structure-activity relationship (SAR) development and discovery of potent indole-based inhibitors of the hepatitis C virus (HCV) NS5B polymerase. J. Med. Chem. 2012, 55, 754-765.

36. Hang, J.Q.; Yang, Y.; Harris, S.F.; Leveque, V.; Whittington, H.J.; Rajyaguru, S.; Ao-Ieong, G.; McCown, M.F.; Wong, A.; Giannetti, A.M.; et al. Slow binding inhibition and mechanism of resistance of non-nucleoside polymerase inhibitors of hepatitis C virus. J. Biol. Chem. 2009, 284, $15517-15529$.

37. Kasahara, Y.; Hikino, H.; Tsurufuji, S.; Watanabe, M.; Ohuchi, K. Antiinflammation actions of ephedrines in acute inflammations. Planta Med. 1985, 51, 325-331.

38. Koster, R.; Anderson, M.; De Beer, E.J. Acetic acid for analgesic screening. Fed. Proc. 1959, 18, 412-416.

39. Ohkawa, H.; Ohishi, N.; Yagi, K. Assay for lipid peroxides in animal tissues by thiobarbituric acid reaction. Anal. Biochem. 1979, 95, 351-358.

40. Jammal, S.; Smith, J.C. Effects of cadmium on glutathione peroxidase, superoxide dismutase and lipid peroxidation in the rat heart: A possible mechanism of cadmium cardiotoxicity. Toxicol. Appl. Pharmacol. 1985, 80, 33-42.

41. Willoughby, D.A.; Moore, A.R.; Colville-Nash, P.R.; COX-1, COX-2, and COX-3 and the future treatment of chronic inflammatory disease. Lancet 2000, 355, 646-648.

42. Holsapple, M.P.; Schnur, M.; Yim, G.K. Pharmacological modulation of edema mediated by prostaglandin, serotonin and histamine. Agents Actions 1980, 10, 368-373.

Sample Availability: Samples of the ten compounds are available from the authors.

(C) 2013 by the authors; licensee MDPI, Basel, Switzerland. This article is an open access article distributed under the terms and conditions of the Creative Commons Attribution license (http://creativecommons.org/licenses/by/3.0/). 